Maurice A. Deane School of Law at Hofstra University Scholarly Commons at Hofstra Law

Hofstra Law Faculty Scholarship

2008

\title{
Postmortem Rights of Publicity: The Federal Estate Tax Consequences of New State-Law Property Rights
}

\author{
Mitchell M. Gans \\ Maurice A. Deane School of Law at Hofstra University \\ Bridget J. Crawford \\ Jonathan G. Blattmachr
}

Follow this and additional works at: https://scholarlycommons.law.hofstra.edu/faculty_scholarship

\section{Recommended Citation}

Mitchell M. Gans, Bridget J. Crawford, and Jonathan G. Blattmachr, Postmortem Rights of Publicity: The Federal Estate Tax Consequences of New State-Law Property Rights, 117 Yale L.J. Pocket Part 203 (2008)

Available at: https://scholarlycommons.law.hofstra.edu/faculty_scholarship/778

This Article is brought to you for free and open access by Scholarly Commons at Hofstra Law. It has been accepted for inclusion in Hofstra Law Faculty Scholarship by an authorized administrator of Scholarly Commons at Hofstra Law. For more information, please contact lawcls@hofstra.edu. 


\section{THE YALE LAW JOURNAL POCKET PART}

MITCHELL M. GANS, BRIDGET J. CRAWFORD \& JONATHAN G. B LATTMACHR

\section{Postmortem Rights of Publicity: The Federal Estate Tax Consequences of New State-Law Property Rights}

California recently passed legislation that creates retroactive, descendible rights of publicity. ${ }^{1}$ The New York State Assembly is poised to enact similar legislation. ${ }^{2}$ Legal recognition of postmortem rights of publicity permits a decedent's named beneficiaries or heirs to control (and financially benefit from) use of a deceased personality's image and likeness. Legislators, proponents of these laws, and legal commentators have overlooked two significant federal estate tax consequences of these new state law property rights. First, a descendible right of publicity likely will be included in a decedent's gross estate for federal estate tax purposes. ${ }^{3}$ Second, the estate tax value of rights of publicity easily could exceed the estate's liquid assets available to pay taxes. These tax concerns could be eliminated, however, by rewriting the statutes to limit a decedent's ability to control the disposition of any postmortem rights of publicity.

\section{BACKGROUND: THE ESTATE OF MARILYN MONROE}

California's legislative recognition of postmortem publicity rights and New York's proposal to do the same respond directly to two lawsuits brought by beneficiaries named in Marilyn Monroe's will. When Monroe died of a drug overdose in 1962, she left the bulk of her estate to her acting coach, Lee Strasberg. When Strasberg died twenty years later, he left most of his estate to his third wife, Anna. In two separate cases, Anna Strasberg asserted her

\footnotetext{
1. Cal. Civ. Code $\$ 3344.1$ (West Supp. 2008).

2. A8836, State Assem., 2007-2008 Reg. Sess. (N.Y. 2007).

3. See Estate of Andrews v. United States, 850 F. Supp. 1279 (E.D. Va. 1994).
} 
exclusive right to control the use of Monroe's likeness and image. Strasberg sought to prevent others, including the heirs of Monroe's photographers, from exploiting those images for commercial purposes in projects undertaken long after Monroe's death. ${ }^{4}$

In one case, brought in federal court in California, ${ }^{5}$ Strasberg sued corporations established by the surviving family members of photographers Milton H. Greene and Tom Kelley, Sr. Greene was a photographer for Look magazine who took thousands of photographs of Monroe. Kelley took an infamous 1949 nude photograph of Monroe that later became the first Playboy centerfold. Strasberg objected to the defendants' use of images of Monroe, claiming that she alone had the right to control Monroe's likeness and image. ${ }^{6}$

In the other case, brought in federal court in New York, ${ }^{7}$ Strasberg sued the corporation established by the heirs of photographer Sam Shaw for a variety of alleged infringements on her exclusive right to publicity, including the unauthorized use of Monroe's image on t-shirts sold at the Target retail chain. Shaw was best known for his publicity photograph for the film The Seven Year Itch, in which Monroe stands on a New York subway grate wearing a billowing white dress.

After U.S. District Courts in both the Central District of California and the Southern District of New York ruled against Strasberg, the state legislatures

4. See, e.g., Laura Parker, Photographers' Heirs Seek a Cut of Monroe Fortune, USA TODAY, Oct. 1, 2007, at 4A, available at http://www.usatoday.com/news/nation/2007-10-01-monroeestate_N.htm (describing the license that Kelley's heirs gave to a winery to use a nude image of Monroe on wine bottles); see also Linda J. Wank \& Elisabeth H. Cavanagh, The Lasting Effect of Star Power, N.Y.L.J., Sept. 17, 2007 , at S1, available at h t t p : / / w w w. fk k law. com/article. as p ? a t i cle I D = 165 .

5. Milton H. Greene Archives, Inc. v. CMG Worldwide, Inc., No. 05 Civ. 2200 (C.D. Cal. May 14, 2007).

6. Both Strasberg and the photographers' heirs sold images of Monroe for several years prior to the commencement of the lawsuits brought to prevent use of Monroe's image in ways that Strasberg did not approve. Strasberg's son is quoted as saying, "We don't want Marilyn on tampons. We don't want sex oils and condoms. We don't want her on cigarettes." Parker, supra note 4 .

The photographers' asserted copyrights in the images did not preclude Anna Strasberg's claim, the U.S. District Court for the Central District of California reasoned, because a claim of the right to control postmortem publicity is distinguishable from a claim of ownership over the rights to the image itself. The court found that Strasberg's asserted right to control Monroe's postmortem publicity was neither within the subject matter of copyright nor equivalent to rights protected by federal copyright law; the claim was therefore not preempted by federal copyright law. Milton H. Greene Archives, Inc., No. 05 Civ. 2200, slip op. at 8-12 (C.D. Cal. May 14, 2007) (citing 17 U.S.C. $\$ 301(a)$ (200o) and Downing v. Abercrombie \& Fitch, 265 F.3d 994, 1003 (9th Cir. 2001)).

7. Shaw Family Archives, Ltd. v. CMG Worldwide, Inc., 486 F. Supp. 2d 309, 310 (S.D.N.Y. 2007). 
responded. On October 10, 2007, Governor Arnold Schwarzenegger approved revisions to the California Civil Code to allow compensatory and punitive damages against anyone who "uses a deceased personality's name, voice, signature, photograph, or likeness, in any manner, on or in the product, merchandise, goods, or for purposes of advertising or selling, or soliciting purchases of, products, merchandise, goods, or services," without the prior written consent of the persons to whom a deceased personality transferred by will or other lifetime instrument his or her post-death "rights in his or her name, voice, signature, photograph, or likeness." ${ }^{8}$ If the decedent did not make such a transfer, in the ordinary course of events these rights would pass onehalf to the deceased personality's surviving spouse and one-half to the decedent's children and grandchildren. ${ }^{9}$ California law now applies these rights even with respect to decedents, like Marilyn Monroe, who died prior to January 1,1985 , the enactment date of an earlier version of the legislation. ${ }^{10}$ (The prior version did not apply to decedents who died before its enactment. ${ }^{11}$ ) In the statute itself, the California legislature explicitly states its intention to overrule the approach taken in the California and New York cases. ${ }^{12}$

The New York bill is similar to the California law except that it makes it a criminal misdemeanor to use without authorization "for advertising purposes, or for the purposes of trade the name, portrait, voice, signature or picture of

8. CAL. CIV. CODE $\$$ 3344.1(a)(1), (b) (West Supp. 2008).

9. $\$ 3344 \cdot 1(\mathrm{~d})(1)$-(4). In the event that a decedent is survived by spouse, but not by children or grandchildren the entire interest would pass to the surviving spouse. Similarly, in the event that a decedent is survived by children or grandchildren, but not a surviving spouse, the entire interest would pass to children and grandchildren. If the decedent is not survived by a spouse, child, or grandchild but is survived by a parent or parents, the rights pass to the surviving parents. If the decedent is not survived by any of the foregoing, the rights of publicity terminate. Id.

10. $\$ 3344 \cdot 1(\mathrm{p})$. The California statute may not help Strasberg. The California federal court recently ruled that because the actress is considered to have been a domiciliary of New York at the time of her death, her estate cannot assert California's statutory postmortem publicity rights. An appeal is expected. See Milton H. Greene Archives, Inc. v. CMG Worldwide, Inc., No. 05 Civ. 2200 (C.D. Cal. Mar. 17, 2008); Nathan Koppel, Monroe Estate Takes Hit, WaLl ST. J., Mar. 31, 2008, at A5.

11. See Milton H. Greene Archives, Inc., No. 05 Civ. 2200, slip op. at 19 (C.D. Cal. May 14, 2007); Shaw Family Archives, Ltd., 486 F. Supp. $2 \mathrm{~d}$ at 319-20.

12. S.B. 771 , State Sen., 2007-2008 Reg. Sess. $\$ 2$ (Cal. 2007). To the extent that any legislation made effective on a retroactive basis would defeat previously conferred vested rights, serious constitutional questions would arise. The constitutional implications are not addressed in this Commentary, but will be the subject of a future article. 
any deceased natural person who died within seventy years prior to [January 1 , 2008]."13

\section{ESTATE TAX INCLUSION OF THE POSTMORTEM RIGHT TO PUBLICITY}

Recognizing a descendible postmortem property right has federal estate tax consequences that state legislators appear not to have considered. Federal estate tax is imposed on the value of all gratuitous death-time transfers made by a decedent. ${ }^{14}$ For the most part, the tax liability will depend on the value of property included in the gross estate. ${ }^{15}$ In the most general terms, all property owned by the decedent at death will be included in the gross estate. ${ }^{16}$ This includes real property, tangible personal property, and intangible personal property, such as intellectual property rights. Descendible property rights to postmortem publicity, as they exist under current California law and under the proposed New York legislation, are property rights that likely will be included in a decedent's gross estate. ${ }^{17}$

\section{VALUATION AND ESTATE TAX LIQUIDITY CONCERNS}

The basic valuation rule is that a decedent's property is valued for federal estate tax purposes at its fair market value as of the decedent's date of death. ${ }^{18}$ Fair market value is "the price at which property would change hands between a willing buyer and a willing seller, neither being under any compulsion to buy or to sell and both having reasonable knowledge of the relevant facts." ${ }^{19}$ In the case of a unique asset, the court will refer to experts' opinions to determine value. The fair market value of postmortem publicity rights will be subject to federal estate tax, unless passing to a surviving spouse under the protection of the estate tax marital deduction or to charity under the protection of the charitable deduction, regardless of whether the decedent's survivors choose to exploit those rights. ${ }^{20}$

\footnotetext{
13. A8836, State Assem., 2007-2008 Reg. Sess. $\$ 1$ (N.Y. 2007).

14. I.R.C. $\$ 2001(a)(2000)$.

15. See id. $\$ 2001(\mathrm{~b})$.

16. Id. $\$ 2033$.

17. See Estate of Andrews v. United States, 850 F. Supp. 1279 (E.D. Va. 1994).

18. I.R.C. $\$ 2031$ (2000); Treas. Reg. $\$ 20.2031-1$ (b) (as amended in 1965).

19. Treas. Reg. $\$ 20.2031-1$ (b) (as amended in 1965).

2O. I.R.C. $\$ 2055$ (2000).
} 
The estate tax inclusion of a decedent's postmortem publicity rights could result in an estate tax liquidity problem common in estates consisting of assets that are difficult to sell or convert to cash. Consider, for example, a hypothetical case of a well-known actor who dies with a twenty million dollar estate-marketable securities worth ten million dollars and descendible postmortem publicity rights valued at ten million dollars. Assume that the actor is not survived by his spouse, and he bequeaths his entire estate to his adult children. For simplicity purposes, assume further that there are no available deductions, credits, exemptions, or exclusions and that the estate tax rate is fifty percent. In this case, the estate will need to use all of the liquid assets to pay the federal estate tax bill of ten million dollars (fifty percent of the twenty million dollar gross estate). Even if the adult children might prefer - for privacy or other reasons-to refrain from exploiting their inherited postmortem rights of publicity, they will need to do so in order to receive any financial benefit from the estate. If the decedent knows that his or her heirs will not want to exploit the rights of publicity, the decedent may be able to extinguish those rights and avoid estate tax inclusion of their value.

\section{A PROPOSAL TO FIX THE FEDERAL ESTATE TAX PROBLEM}

There is a relatively simple legislative solution to the problem of federal estate inclusion of descendible postmortem rights to publicity. Under the California law as drafted, the decedent's ability to designate who will receive his or her postmortem publicity rights triggers the imposition of federal estate tax. $^{21}$ If, however, state law were modified to provide that the postmortem rights of publicity pass automatically to a decedent's surviving spouse and descendants then the value of those rights should not be subject to federal estate taxation. ${ }^{22}$

An unrestricted postmortem publicity right that survives a decedent's death likely will receive estate tax treatment similar to certain tort claims that survive a decedent's death. For example, included in a decedent's gross estate for federal estate tax purposes is the value of heirs' post-death claims for a decedent's lifetime pain and suffering. ${ }^{23}$ By parity of reasoning, then, the value

\footnotetext{
21. Id. $\$ 2036(\mathrm{a})(2)$.

22. This is because the decedent had no interest in the financial benefit generated by the postmortem publicity rights. See Richard B. Stephens et al., Federal Estate and Gift TAXATION $94.05[8]$ (8th ed. 2002).

23. I.R.C. $\$ 2033$ (2000); Rev. Rul. 75-127, 1975-1 C.B. 297 (asserting the IRS's position that wrongful death proceeds that represent damages to which the decedent had become entitled during his lifetime are includible in the gross estate); RESTATEMENT (SECOND) OF TORTS $\$ 926$ (1977) (stating that under survival statutes, a decedent's heirs may recover for harm
} 
of publicity rights that may be enforced by a decedent's heirs after his or her death should be included in the gross estate. But if postmortem publicity rights pass only to specific individuals designated by statute and not by the decedent, then the value of those rights should not be included in the decedent's gross estate, by analogy to wrongful death benefits.

Under state-law wrongful death actions, statutorily-designated individuals - not necessarily the beneficiaries under a decedent's will-have the right to sue for the decedent's wrongful death. Because the decedent has no ability to control who succeeds to such a right, the value of a wrongful death action (unlike an heir's tort claim for a decedent's lifetime pain, for example) is excluded from the decedent's gross estate for federal estate tax purposes. ${ }^{24}$ By revising the California and New York statutes to provide that postmortem rights pass automatically to the decedent's surviving spouse and descendants (or if none, to other collateral relatives, as in an intestacy statute), such rights should not be subject to federal estate taxes.

It may be possible to give the decedent the ability to extinguish the postmortem rights without causing estate tax inclusion. As a policy matter, the estate tax is designed to tax transfers by a decedent to others. If a decedent himself or herself destroys an asset immediately prior to death, the value of the asset cannot be included in the gross estate. ${ }^{25}$ Therefore if a decedent were to direct his or her executor, for example, to destroy or extinguish certain assets after the decedent's death, at least one case suggests that the value of such asset should not be included in the decedent's gross estate. ${ }^{26}$ From a policy perspective the decedent who orders the postmortem destruction of an asset has made no greater a transfer to his or her beneficiaries than if the decedent himself or herself had destroyed the asset immediately prior to death. Therefore estate tax should not be imposed on the value of property rights that are destroyed or extinguished in accordance with directions contained in the decedent's will.

A statute that confers postmortem publicity rights on specific individuals while also giving a decedent the right to extinguish those rights might appear to be inefficient, in that it could lead to the elimination of property that has potential economic value. But such a rule would encourage no greater economic loss or non-productivity than existed prior to the recently enacted

suffered by the decedent before death). Cf. Rev. Rul. 69-8, 1969-1 C.B. 219 (asserting the IRS's position that damages recoverable for the pain and suffering of the decedent are includible in the decedent's gross estate).

24. See Maxwell Trust v. Comm'r, 58 T.C. 444 (1972), acq., 1973-2 C.B. 2.

25. Cf. I.R.C. $\$ 2033$ (200o) (providing that the value of the decedent's gross estate is determined by the extent of his interest at the time of death).

26. Ahmanson Found. v. United States, 674 F.2d 761 (9th Cir. 1981). 
legislation that first recognized these retroactive postmortem publicity rights. Moreover the uniquely personal nature of one's image and likeness suggests that individuals should have at least the ability to prevent a statutorily named individual or group of individuals from benefiting exclusively from his or her image or status post-death.

Mitchell M. Gans is the Steven A. Horowitz Distinguished Professor of Tax Law at Hofstra University School of Law and an Adjunct Professor at New York University School of Law. Bridget J. Crawford is an Associate Professor at Pace University School of Law. Jonathan G. Blattmachr is a Member of Milbank, Tweed, Hadley \& McCloy LLP and the head of that firm's Trusts \& Estates group. The authorswelcome commentsatlawmmg@hofstra.edu; bcrawford@law.pace.edu; and jblattmachr@milbank.com.

Preferred Citation: Mitchell M. Gans, Bridget J. Crawford \& Jonathan G. Blattmachr, Postmortem Rights of Publicity: The Federal Estate Tax Consequences of New State-Law Property Rights, 117 YALE L.J. POCKET PART 203 (2008), http://thepocketpart.org/2008/o4/o1/ganscrawfordblattmachr.html. 